\title{
The Elements of Accounting Information Systems and the Impact of Their Use on the Relevance of Financial Information in Wahda Bank-Benghazi, Libya
}

\author{
Tarek Abdelhafid Elsharif \\ Higher Institute of Administrative and Financial Sciences, Benghazi, Libya \\ Email: tarek.a.elsharif@gmail.com
}

How to cite this paper: Elsharif, T.A. (2019) The Elements of Accounting Information Systems and the Impact of Their Use on the Relevance of Financial Information in Wahda Bank-Benghazi, Libya. Open Journal of Business and Management, 7, 1429-1450.

https://doi.org/10.4236/ojbm.2019.73098

Received: June 7, 2019

Accepted: July 23, 2019

Published: July 26, 2019

Copyright $\odot 2019$ by author(s) and Scientific Research Publishing Inc. This work is licensed under the Creative Commons Attribution International License (CC BY 4.0).

http://creativecommons.org/licenses/by/4.0/

\section{Open Access}

\begin{abstract}
Accounting information systems with their elements (people, procedures and instructions, data, software, information technology infrastructure, and internal control) are an essential factor in decision making in economic units, where the use of accounting information systems and their fast development day after day have led to a continuous and rapid change in the outputs of these systems, thus contributing to the efficiency and effectiveness of the financial reports and financial information contained therein, in terms of speed, objectivity, detail, and suitability. Hence, what distinguishes this study is that the accounting information systems have studied at the level of its six elements. Thus, the objectives of this study are to clarify and determine the reality of the use of accounting information systems at the level of these variables and measure the impact of this use on the relevance of financial information in Wahda bank. The results designate that there just three elements from accounting information systems elements (namely People, Data, and Internal Controls) impact positively on the relevance of financial information. Thus, these three elements are the critical factors in explaining the effect on the relevance of financial information in Wahda Bank-Benghazi, Libya. Therefore, any increase in these elements will increase the relevance of financial information. Therefore, the study suggested a set of recommendations, the most important of which was to increase attention to accounting information systems and to increase the concentration and awareness of the importance of international accounting standards within Wahda bank.
\end{abstract}

\section{Keywords}

Accounting Information Systems, Accounting Information System Elements, 
The Relevance of Financial Information

\section{Introduction}

All firms are struggling to heighten their profitability and their revenues within the utilization of available source and make fast decisions based on proper and right information instantly which in this issue has raised the point of accounting information systems. That is not bounded by the private strip corporations only, but also, the governmental organizations are seeking to accomplish the same prior goals and to contribute to the balance of the payments of these organizations. Accounting information systems as a part of the administration information systems represent the most effective systems in the economic unity, and these organizations varied amongst each other in terms of the application of accounting information systems and the awareness of their importance [1].

High-quality accounting information is of crucial importance for a vast number of users as it influences the quality of the decisions made. So, present useful and high-quality accounting information is a precondition for the efficiency of the corporation. The usefulness of the accounting information usually linked to the extent that this information is matching the particular requirements at any specific time and also how this information contributes to the resolve of a specific problem, and the usefulness identified by the accounting information quality, by useful information that means the sort of information that its consumer features, is essential and required by its users; is delivered on time and is used for performing a specific activity, moreover, for the enforcement of indirect or direct link/feedback among the users and the creators of accounting information [2].

The significant improvement in recent decades of the Banks' sector in Libya - which will be the focus of this study-witnessed by well as intense competition and the growing presence in the business environment, so has to be an evaluation of the role played by accounting information systems impact on the quality of the information provided by these tools and what is the benefit derived from the technology used. As due to technological and economic developments and globalization, information systems have developed at a quick frequency and have been performed at every level of management. These programs have been used in operational, technical and strategic levels which provide important information to all user groups of accounting information [3].

Moreover, each firm has decision makers, external and internal, who require information to conduct decisions. The primary sort of required information is accounting information. In general, the accounting information is given by financial reports. Concisely, accounting information performs an essential function in the decision-making process at organizations [4] [5] [6]. 


\section{Literature Review}

\subsection{Accounting Being a System for Information}

Accounting information systems are currently responsible for providing financial and quantitative information to all departments and other parties. So, accounting information systems are stopping at the crossroads between two specialties: "accounting" and "information systems". Therefore, the research of AISs is usually viewed as a study of computerized systems of accounting. But because we cannot define an AIS by its magnitude, it is preferable to define it by what it does. This latter approach drives us to the following definition accounting information system is a group of data and processing procedures that creates needed information for its users" [7].

[8] indicated accounting information systems as a subsystem of information inside the companies. It assembles information from the different subsystems of the organization and communicates it to the organization's information processing the primary system. The system of accounting information has commonly focalized on gathering, processing, analyzing and communicating financial information to outside parties such as creditors, investors, bankers, and tax agencies and inside parties such as management and owners. Nowadays, the accounting information system is concerned with fiscal as well as non-fiscal information.

The essential mission of (AIS) is to allocate a quantitative value of the past, current and future business events. Accounting Information System with the help of the automated accounting system presents the financial statements, cash flow statement, earnings statements, and balance sheet. The system will process the data and converted into accounting information. During the input phase, a processing phase, and output phase, it will use by an extensive variety of users such as internal and external users. An effective Accounting Information System accomplishes several essential functions like data collection, maintenance, data Accounting Information Systems, and data control and information generation [9].

[10] designates to Accounting Information system as a portion of the company's information system which helps the company in providing processed information. This processed and arranged information assists the management into taking the decision and which has a high impact on organizational profitability. The excellent information provides efficiency, consistency and internal control of the organization.

Also, [11] defined it as "one of the components of an administrative organization that deals with the collection, delivery, analysis, processing, and classification of material and quantitative information to present decisions to the internal and external parties". Accordingly, accounting information systems are a fundamental piece of the administrative organization. Accounting information systems can consider being one of Management Information Systems (MIS) components, which is concerned with providing data and objectivity information that affect the company's activities as an entire for making the proper decisions 
to help achieve the aims.

\subsection{Elements of the Accounting Information System}

The accounting information system is like any system consisting of a set of elements to achieve its goal. So, we find that accounting information systems commonly formed of six main elements: people, instructions and procedures, software, data, information technology infrastructure and internal controls [12] [13] [14].

The following is an explanation of each component in detail.

\subsubsection{People (the Human Element)}

The people in the systems of accounting information are the system users. Professionals who may require using an organization's accounting information systems involve accountants, business analysts, consultants, managers, auditors, and chief financial officers. The system of accounting information also facilitates obtaining information to the exterior user of the organization when wanted. For instance, consultants may use the information in the accounting information system to analyze the effective performance of the pricing structure of the company by looking at sales data, cost data, and revenue. The AIS must be designed to fulfil the requirements of the people who will be utilizing it. Furthermore, the system must be smooth and easy to use and should improve efficiency and not hinder it.

\subsubsection{Procedure and Instructions}

The procedure and instructions of the accounting information system are the techniques and methods that utilize for collecting, saving and storing, retrieving and processing data. These automated and manual techniques will be both, and the data can arrive from both inside sources (e.g. employees) and outside sources (e.g. online customers orders). Procedures and instructions requirement be followed consistently to be adequate to fulfil the requests and needs of different users and different sorts of information.

\subsubsection{Data}

The data included in the accounting information system is all the financial information related to the business practices of the organization. So whatever business data that influence the finances of the firm it should go into the system of accounting information. The data included in the accounting information system based on the nature of the business. This data can thereupon be utilized to prepare accounting reports and statements like tables of depreciation or amortization, accounts receivable aging, trial balance, profit and loss, and so on. The existence of all this data in one position-in the system of accounting information-helps and supports recordkeeping, reporting, analysis, auditing, and decision-making activities, of the business. For the data to be beneficial, it should be complete, correct and relevant. 


\subsubsection{Software}

The software element of the accounting information system is the computer software utilized to save, retrieve, store, process and analyze the firm's financial data. Before computers exist, accounting information systems were hand-operated, paper-based systems, but nowadays, most firms are applying computer software as the basis of the system of accounting information. Reliability, quality, and security are fundamental elements to the useful software for the accounting information system. Managers rely upon information that produces by the system to make suitable resolutions of the company, and they want high-quality information to perform these proper decisions. Accounting information systems programs can be designed to fulfill the unique demands of various sorts of businesses. If an existing program does not fulfill a company's requirements, the software can likewise be developed in-house with extensive input from end users or can be developed by another company specifically for the organization.

\subsubsection{Information Technology Infrastructure}

This element is just an elegant name for the equipment and hardware utilized for operating the system of accounting information. Most of these hardware and equipment items are tools business would need it to have; hence they include personal computers, storage devices, printers, servers, routers, and probably the backup power supply. Besides to the cost of these components should consider whether they include a combination of factors including storage capacity, speed, and memory size and whether they are scalable and upgradeable Perhaps most importantly, the hardware selected for an accounting information system must be compatible with the intended software.

Furthermore, a perfect accounting information system ought to include a scheme for safeguarding, servicing, upgrading and replacing components of the hardware system, as well as a plan for the getting rid of inefficient and outdated hardware so that sensitive data wholly destroyed.

\subsubsection{Internal Controls}

This element of the accounting information system is the protection and security procedures and measures it includes to protect critical data. These can be as complicated as biometrics identification or as easy as passwords. So, the (AIS) should consist of internal controls to safeguard against illegal and unauthorized computer access and to curb access to the authorized users in the organization. Likewise, it must also deter unauthorized file access by users who are authorized to enter only into specific sections of the system. A system of accounting information involves secret information not relating just to the firm but further to its customers and employees. These data may include credit card numbers, National ID numbers, numbers of social security, salary information, and so on. The whole of the data in the (AIS) must be cryptographic, and it is needful to access to the system ought to be logged in and monitored. Also, system activity should 
be evident and traceable. Moreover, an accounting information system requires internal controls that shield it from computer viruses, hackers, and other inside and outside dangers that threats to the security of the network.

\subsection{The Relevance of Financial Information}

For information to be beneficial, it must be relevant to the needs of decision makers. To relevant, the information ought to be related to the decision and thus affect the economic decisions of users by assisting them to assess previous, current, and coming events or modify the previous assessment process [15] [16].

According to the framework, pertinent financial information is able of creating a change in the decisions made by users. Financial information can make a change into making decisions if it owns confirmatory value, predictive value, or both together. We should mention that the confirmatory value and predictive value of financial information are interrelated [17] [18].

\subsubsection{Definitions of Value Relevance}

In line with the description above, users of financial statements need the assistance of financial reports in valuing a company. If there is no association between accounting figures presented in financial statements and the company value, accounting information cannot be claimed to be value relevant. Many studies investigate the relationship between capital markets and accounting information presented in the financial statements. Empirical research analyzing the relationships between capital markets and financial statements generally referred to as capital markets-based accounting research (CMBAR). According to [19], modern CMBAR originated with the articles of [20] [21].

According to [22], although the literature examining such associations dates back to more than 30 years like the study of [23], the term value relevance was firstly used by [24]. Where they used this term while comparing US versus Non-US GAAP accounting figures, they use the value relevance term while evaluating the associations between accounting earnings and security returns. According to [25], the study of [23] is the oldest earnings approach that characterizes value as the present value of permanent future earnings.

Another definition belongs to [26] who defined value relevance as "the ability of earnings to explain annual market-adjusted returns; and the ability of earnings and book values of assets and liabilities to explain market values of equity".

According to [22] [25] [27], an accounting number is termed as "value relevant" if it is significantly related to the market value.

As seen, there are many definitions, and definitions of value relevance can interpret in many ways. In line with the literature on value relevance, this study defines accounting information as value relevant if it is related to the market return of the firm.

\subsubsection{Value Relevance of International Accounting Standards}

The financial reporting practices of companies in different countries vary. That 
leads to enormous complications for those preparing, consolidating, auditing and interpreting financial statements. In order to deal with these complications, organizations in different parts of the world have to harmonize or standardize accounting.

Undoubtedly, globalization makes universal accounting standards inevitable. The markets naturally attract investors that they understand and confidence them. Besides, investors, analysts, employees, creditors, suppliers, customers, lenders, and non-governmental organizations collectively express their needs for comprehensive information to give their decisions. They desire to compare the accounting information produced by a target company with its competitors located in its home country or other parts of the world. Therefore, states which adopt internationally recognized accounting standards for financial reporting will position at a significant advantage over those that do not.

According to [28], the advantages of International Financial Reporting Standards (IFRS) for investors are as follows;

1) More accurate, comprehensive and timely information compared to the national standards they replace in the countries adopting them.

2) Increase in the quality of financial reporting that allows a decrease in the risk.

3) Elimination of many international differences in accounting standards and standard reporting formats-which makes a company's financial statements more internationally comparable.

4) Reducing the cost of processing financial information and increasing the stock market efficiency by reflecting this information on prices.

5) With the decrease in international differences, removing barriers for potential cross-border acquisitions and mergers, thereby providing investors with increased takeover advantages.

With the adoption of internationally recognized accounting standards for financial reporting, an increase in accounting information quality expected, because one of the main objectives of firms using IFRS is to report high quality, comparable and transparent information in financial statements. These requirements and considerations have motivated by many researchers for investigating the perception of investors who have adopted IFRS. One of the methods to measure this perception is testing the value relevance of accounting information before and after the IFRS adoption. Researchers in this area test the ability of financial statements to capture changes in share values.

[29] investigated the market valuation of earnings and book value amounts prepared under IAS and US-GAAP for the years 1992-1996. They find evidence that the US-GAAP earnings reconciliation amounts are value-relevant after controlling for IAS amounts for market value and return models. They also see that earnings reconciliation amounts under IAS more highly associated with price-per-share than US-GAAP amounts and that US-GAAP amounts more highly associated with security returns than IAS amounts.

[30] examined the value relevance of earnings under Local Accounting Stan- 
dards and their voluntarily disclosed reconciliations to the International Accounting Standards in Finland during 1984-1992. The findings suggest that earnings under Local Accounting Standards have significant value relevance to both domestic and foreign investors. Even after the revenues controlled under Local Accounting Standards, the aggregate reconciliation of Local Accounting Standards to IAS earnings does not give significant value relevance.

[31] investigated the relative value relevance of earnings reported under German GAAP, US-GAAP, and IFRS. The research sample included 417 German companies listed in local stock markets during the period 1998-2000. According to their sample, value relevance of US-GAAP according to earnings is higher than that of IFRS based earnings, which in turn is more relevant than those produced under the German GAAP.

[32] examined the incremental value relevance of the reconciliation of accounts from the Chinese Accounting Standards to the International Accounting Standards by those Chinese listed companies that have simultaneously issued $\mathrm{A}$ shares and B shares for the period 1995-2000 (A-shares issue in China under Chinese law, B-shares are foreign-invested shares issued by companies domestically according to International Standards). Their study shows that earnings and book values of equity determined under Chinese Stock Market Rules. The reconciliation of earnings and book values from Chinese Accounting Rules to IAS is partially value-relevant, mainly to stock prices in the B-share market, while the earnings reconciliation is generally not value-added to stock returns in either the A- or the B-share market. So, the study of Lin \& Chen, (2005) suggests that accounting numbers are more value-relevant based on Chinese Stock Market Rules in contrast to IAS.

[33] investigated the impact of IFRS for 35 firms listed in the IBEX (Spanish Exchange Index) in 2005. The study reveals that historical comparability is negatively affected if both IFRS and local accounting standards applied in the same country at the same time. They also find that there has been no improvement in the relevance of financial reporting because the gap between book and market values is wider when IFRS is applied.

[34] analysed the impact of IFRS on accounting quality in Italy from 2002 to 2007. The findings indicate that accounting quality after IFRS adoption decreases concerning earnings management. Empirical evidence shows an increase in earnings smoothing and a decrease in earnings timeliness. On the other hand, results of value relevance tests highlight an improvement in the ability of accounting numbers to make a decision. Findings of [34] have important implications. For example, moving towards high-quality accounting standards is not sufficient, so there should also be a guarantee for improvement in accounting quality.

\section{Statement of the Problem}

The problem of study concentrates on the effect of the utilizing of accounting information systems on the relevance of financial information in Wahda bank, 
and the capability of the accounting information systems to present the financial information to be submitted to resolve the problem of relevance; as the most essential element on financial information quality elements, which are considered the essence of financial accounting and the primary objective of using the accounting system.

This study attempted to answer the following main question:

"Does use accounting information systems has an impact on the relevance of financial information in Wahda Bank?"

This major question leads to the next sub-questions:

1) Does use People has an impact on the relevance of financial information in Wahda Bank?

2) Does use Procedure and instructions has an impact on the relevance of financial information in Wahda Bank?

3) Does use Data has an impact on the financial information Relevance in Wahda Bank?

4) Does use Software has an impact on the relevance of financial information in Wahda Bank?

5) Does use Information Technology Infrastructure has an impact on the relevance of financial information in Wahda Bank?

6) Does use Internal Controls has an impact on the relevance of financial information in Wahda Bank?

\section{Objectives of Study}

Financial information quality has gained great plenty of attention across the world, empirically and academically. Therefore, the primary mission of Accounting Information Systems is to produce information based on the processing of data resulting from financial transactions. This sort of information generally is the support and foundation of information systems management accounting and is considered as a system for identifying, collecting, processing and exchange of financial and other data which utilized to support decision making.

So, this research will focus on the evaluation of the impact of using accounting information systems-with its six elements-on the relevance of financial information as an essential element of accounting information quality elements in Wahda Bank.

Also, this study distinguished from other previous studies, where it went deeply into the search for the impact of accounting information systems by examining the effect of each element of accounting information systems in more detail, with a focus on one aspect of the accounting information quality elements which is the relevance.

\section{Methodology}

This part of the study shows the study population, tools, model and hypotheses, moreover statistical methods which were used. 


\subsection{Method of Measure Research Variables}

As regard, this study has deepened in the analysis of accounting information systems by studied its six elements. Therefore, these elements dealt with as the variables and dimensions of this study.

Therefore, according to the research objectives and questions, we include in Table 1 previous studies carried out by academic researchers in the same subject, on which the researcher based on this study.

\subsection{Study Model}

The study model consists of six main variables were (People Element, Procedures and Instructions Element, Data Element, Software Element, Information Technology Infrastructure Element, and Internal Controls Element) as variables that measure the uses of accounting information systems [independent variables], and relevance of financial information as a dependent variable, as shown in Figure 1.

Table 1. Definitions and measurements of study variables.

\begin{tabular}{|c|c|c|c|}
\hline Variable & & nsions/Elements & Literature \\
\hline \multirow{6}{*}{$\begin{array}{c}\text { Independent } \\
\text { Variables } \\
\text { (Accounting } \\
\text { Information } \\
\text { Systems) }\end{array}$} & $\mathrm{PE}$ & People & \multirow{6}{*}{$\begin{array}{c}\text { [1] Abdallah, (2014) } \\
\text { [35] Alzoabaie, (2001) } \\
\text { [36] Aldaya, (2009) }\end{array}$} \\
\hline & PI & $\begin{array}{c}\text { Procedures } \\
\text { and Instructions }\end{array}$ & \\
\hline & DA & Data & \\
\hline & SW & Software & \\
\hline & IT & IT Infrastructure & \\
\hline & IC & Internal Controls & \\
\hline \multirow{5}{*}{ Dependent Variable } & \multirow{5}{*}{$R$} & \multirow{5}{*}{ The Relevance } & [15] Aljawhar, (2011) \\
\hline & & & [22] Barth et al., (2001) \\
\hline & & & [37] Alshami, (2009) \\
\hline & & & [38] Beest et al., (2009) \\
\hline & & & [39] Abuharb, (2009) \\
\hline
\end{tabular}

Independent Variable

Dependent Variable

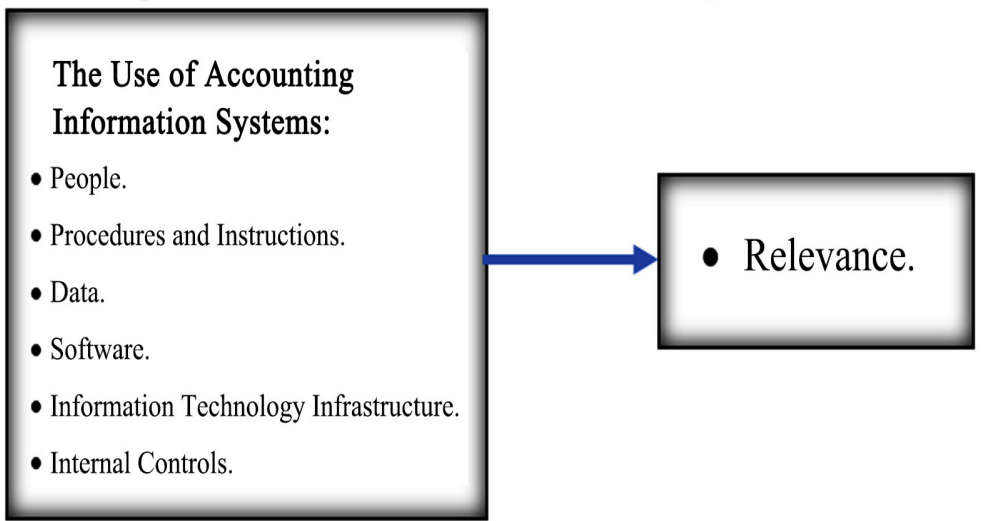

Figure 1. The study model. 


\subsection{Study Hypotheses}

Based on the theoretical framework of the study, based on the study's questions and objectives, and reviewing the Literature, the main hypotheses of the study can be formulated as follows:

$H_{0}$ : There is no statistically significant impact of using accounting information systems on the relevance of financial Information in Wahda bank.

$H_{1}$ : There is a statistically significant impact of using accounting information systems on the relevance of financial Information in Wahda bank.

$H_{0}: \mu<3$.

$H_{1}: \mu \geq 3$.

This main hypothesis leads to the following sub-hypotheses:

$H_{1 a}$ : There is a statistically significant impact of using the (People) element on the Relevance of financial information in Wahda bank.

$H_{1 b}$ : There is a statistically significant impact of using the (Procedures and Instructions) element on the relevance of financial information in Wahda bank.

$H_{1 c}$ : There is a statistically significant impact of using the (Data) element on the Relevance of financial information in Wahda bank.

$H_{1 d^{*}}$ There is a statistically significant impact of using the (Software) element on the Relevance of financial information in Wahda bank.

$H_{1 e}$ : There is a statistically significant impact of using the (Information Technology Infrastructure) element on the Relevance of financial information in Wahda bank.

$H_{1 \dot{r}}$ There is a statistically significant impact of using the (Internal Controls) element on the Relevance of financial information in Wahda bank.

\subsection{Population and Sample}

The target population of the study consists of all financial people working in accounts and budget department in Wahda Bank. So, all information about questionnaires distributed, received and which are valid for analysis were summarized in Table 2.

\subsection{Study Instrument}

The study strategy developed a framework for designing a questionnaire according to previous studies. That would support to address the study's objectives and questions. The questionnaire divided into three sections as the first one includes general questions; the second one covers all elements of the independent variables. Finally, the third one involves the dependent variable, as shown in $\mathrm{Ta}$ ble 3.

\subsubsection{Normality Distribution Test}

This test is used to determine if the data of given variables follows natural distribution or not, and testing is necessary in the case of hypotheses testing since most parametric tests require that the data be distributed naturally or that the sample size is sufficiently large. 
Table 2. Distributed, collected, excluded and valid questionnaires.

\begin{tabular}{ccccc}
\hline Distributed & Collected & Excluded & Valid & $\%$ \\
\hline 60 & 50 & 4 & 46 & $77 \%$ \\
\hline
\end{tabular}

Table 3. Number of questions related to dimensions.

\begin{tabular}{|c|c|c|c|c|}
\hline Section & Variables & & Dimensions & Questions \\
\hline 1 & General Questions & - & Demographic Questions & $1-6$ \\
\hline \multirow{6}{*}{2} & \multirow{6}{*}{$\begin{array}{c}\text { (Accounting Information } \\
\text { Systems) Independent } \\
\text { Variables }\end{array}$} & $\mathrm{PE}$ & People & $7-11$ \\
\hline & & PI & Procedures and Instructions & $12-16$ \\
\hline & & DA & Data & $17-21$ \\
\hline & & SW & Software & $22-26$ \\
\hline & & IT & IT Infrastructure & $27-31$ \\
\hline & & IC & Internal Controls & $32-36$ \\
\hline 3 & Dependent Variable & $R$ & $\begin{array}{l}\text { (The Relevance of Financial } \\
\text { Information) }\end{array}$ & $37-45$ \\
\hline
\end{tabular}

The answers to paragraphs (2, and 3) were according to a five-point Likert scale.

Since our sample size is less than 50, the (Shapiro-Wilk) test will be used to test whether the data follows the normal distribution. The results of the Tests of Normality Distribution or not, presented in Table 4.

It is clear from the results shown in Table 3 that the probability value (Sig.) For all study variables was higher than the $(\alpha=0.05)$ level. That implies that the distribution of data follows the normal distribution. And also Figure 2 admit that. Therefore, parametric tests were used.

\subsubsection{The Stability of the Questionnaire}

For reliability analysis, Cronbach's coefficient alpha was calculated to determine whether there was consistency in which the participants answered the questions for each factor. It is a measure to evaluate the variables in the scale whether they are positively related to each other or not. According to most researchers, instruments should have a reliability of 0.60 or higher [40] [41], and this result supports the internal consistency of the items.

The stability of the study instrument was verified. Where the $\alpha$-Cronbach coefficient was computed for each set of questionnaire questions, where all measures in this study show a high level of reliability, ranging from ( 0.663 to 0.862 ). All scales exceeded 0.60 , therefore the survey is considered reliable as shown in Table 5.

\subsubsection{The Validity of the Structure}

Also, for the reliability of the instrument, the researcher used the validity of the structure. It is a measure of instrument reliability that measures the extent to which the objectives of the tool achieved. Where measures the extent to which each area of study is closely related to the total score of the questionnaire paragraphs [42]. Table 6 shows the result of this test. 


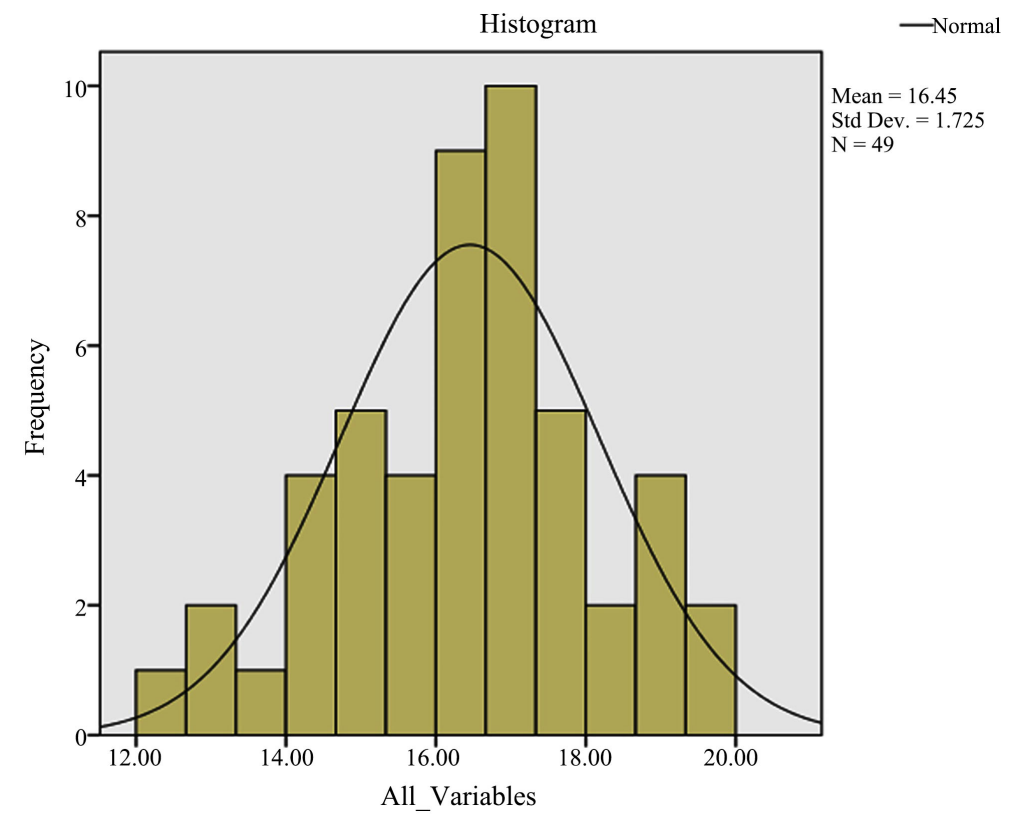

Figure 2. Normality distribution test.

Table 4. Normality distribution test.

\begin{tabular}{cccc}
\hline Variables & \multicolumn{3}{c}{ Shapiro-Wilk } \\
\cline { 2 - 4 } & Statistic & $\mathrm{df}$ & Sig. \\
\hline $\begin{array}{c}\text { People } \\
\text { Procedures } \\
\text { and Instructions }\end{array}$ & 0.977 & 46 & 0.501 \\
Data & 0.963 & 46 & 0.508 \\
$\begin{array}{c}\text { Software } \\
\text { Information Technology } \\
\text { Infrastructure }\end{array}$ & 0.955 & 46 & 0.717 \\
Internal Controls & 0.950 & 46 & 0.459 \\
Relevance & 0.970 & 46 & 0.278 \\
& 0.919 & 46 & 0.353 \\
& 0.969 & 46 & 0.259 \\
\hline
\end{tabular}

Table 5. The stability of the questionnaire (Cronbach's $\alpha$ ).

\begin{tabular}{|c|c|c|}
\hline Variables & Instruments & Cronbach's $\alpha$ \\
\hline \multirow{6}{*}{$\begin{array}{l}\text { Independent } \\
\text { Variables }\end{array}$} & People & 0.750 \\
\hline & $\begin{array}{c}\text { Procedures } \\
\text { and Instructions }\end{array}$ & 0.633 \\
\hline & Data & 0.688 \\
\hline & Software & 0.762 \\
\hline & $\begin{array}{l}\text { Information Technology } \\
\text { Infrastructure }\end{array}$ & 0.806 \\
\hline & Internal Controls & 0.862 \\
\hline $\begin{array}{c}\text { Independent } \\
\text { Variables }\end{array}$ & Relevance & 0.812 \\
\hline
\end{tabular}


Table 6. Validity of the structure.

\begin{tabular}{cccc}
\hline Variables & Instruments & Correlation & Sig. \\
\hline & People & $0.656^{* *}$ & 0.000 \\
Independent Variables & Procedures and Instructions & $0.673^{* *}$ & 0.000 \\
& Data & $0.680^{* *}$ & 0.000 \\
& Software & $0.797^{* *}$ & 0.000 \\
& Information Technology Infrastructure & $0.792^{* *}$ & 0.000 \\
Independent Variables & Internal Controls & $0.654^{* *}$ & 0.000 \\
& Relevance & $0.772^{* *}$ & 0.000 \\
\hline
\end{tabular}

${ }^{* *}$ Correlation is significant at the 0.01 level (2-tailed).

\section{Results}

\subsection{Demographic and Descriptive Statistics}

In this section descriptive analysis was used to analyze the demographic data, to determine the characteristics of the participants. Table 7 summarizes the results.

In the beginning, it is required to indicate the percentage of demographic information for participants in this study, where Table 7 covers demographic information including gender, age, level of education, specialization, and experience years. The results indicate that $63 \%$ of participants were males, $37 \%$ were females and $63 \%$ of the participants were aged between 21 and 40 years of age and about $72 \%$ of the respondents were university graduates, of whom nearly $61 \%$ were bachelor's degree holders.

Table 7 also reveals that the specialization of the participants in this study was distributed to about 59\% accounting, about 20\% financing and banking, and about $22 \%$ business management and about $89 \%$ of participants have 20 years or less of experience.

All demographic results in Table 7 indicate that the sample members have a good experience and they are better qualified to understand the subject of study and to expressing valid opinions in answering the questionnaire.

\subsection{Data Analysis}

\subsubsection{Correlation Analysis}

The strength of the relationship between variables is shown in Table 8 . Where Pearson's correlation analysis conducted, it is clear from the first view that there is a significant correlation between the dependent variable and the independent variables. All the independent variables with their six components have a statistically positive correlation coefficient at a level of significance $(0.05)$ where the level of significance for each paragraph was less than (0.05). The results confirm that all variables have from medium to a strong relationship with each variable $(r>0.400$ level). There is a medium positive correlation between the relevance of financial information, People, Procedures and Instructions, Data, Software, Information Technology Infrastructure, and Internal Controls. 
Table 7. All characteristics of responders.

\begin{tabular}{|c|c|c|c|}
\hline Characteristics & Elements of Characteristics & Frequency & Percent \\
\hline \multirow{3}{*}{ Gender } & Male & 29 & 63.0 \\
\hline & Female & 17 & 37.0 \\
\hline & Total & 46 & 100.0 \\
\hline \multirow{5}{*}{ Age } & 21 - 30 years & 14 & 30.4 \\
\hline & $31-40$ years & 15 & 32.6 \\
\hline & $41-50$ years & 15 & 32.6 \\
\hline & More Than 50 years & 2 & 4.3 \\
\hline & Total & 46 & 100.0 \\
\hline \multirow{5}{*}{ Level of Education } & Diploma & 3 & 6.5 \\
\hline & Higher Diploma & 10 & 21.7 \\
\hline & Bachelor & 28 & 60.9 \\
\hline & Master & 5 & 10.9 \\
\hline & Total & 46 & 100.0 \\
\hline \multirow{4}{*}{ Specialization } & Accounting & 27 & 58.7 \\
\hline & Financing and Banking & 9 & 19.6 \\
\hline & Business Management & 10 & 21.7 \\
\hline & Total & 46 & 100.0 \\
\hline \multirow{4}{*}{ Experience Years } & $0-10$ years & 20 & 43.5 \\
\hline & $11-20$ years & 21 & 45.7 \\
\hline & Over 20 years & 5 & 10.9 \\
\hline & Total & 46 & 100.0 \\
\hline
\end{tabular}

Table 8. Pearson correlation test between variables of study.

\begin{tabular}{|c|c|c|c|c|c|c|c|c|}
\hline No. & Dimensions & 1 & 2 & 3 & 4 & 5 & 6 & 7 \\
\hline 1 & Relevance & 1 & & & & & & \\
\hline 2 & People & $0.534^{\star *}$ & 1 & & & & & \\
\hline 3 & Procedures and Instructions & $0.559^{* *}$ & $0.444^{* *}$ & 1 & & & & \\
\hline 4 & Data & $0.671^{\star *}$ & $0.478^{\star *}$ & $0.446^{* *}$ & 1 & & & \\
\hline 5 & Software & $0.534^{\star *}$ & $0.368^{\star}$ & $0.614^{* *}$ & $0.582^{* *}$ & 1 & & \\
\hline 6 & $\begin{array}{c}\text { Information } \\
\text { Technology Infrastructure }\end{array}$ & $0.540^{\star *}$ & $0.425^{\star *}$ & $0.338^{\star}$ & $0.425^{\star *}$ & $0.600^{* *}$ & 1 & \\
\hline 7 & Internal Controls & $0.686^{* *}$ & $0.326^{*}$ & $0.620^{* *}$ & $0.639^{* *}$ & $0.638^{\star *}$ & $0.554^{\star *}$ & 1 \\
\hline
\end{tabular}

${ }^{* *}$ Correlation is significant at the 0.05 level (2-tailed), $\mathrm{N}=46$.

\subsubsection{Regression Analysis}

Causal research hypotheses were tested by multiple regression analysis. A simple regression provides information on direction and power of a relation between two variables where multiple regression contribute information on how effective more than one independent variable on one dependent variable [43]. 
Where in this part, the impact of using accounting information systems on the relevance of accounting information was tested using regression analysis (Stepwise Method) between the independent variables and the dependent variable for test study hypotheses, With the level of significance $(\alpha)$ set at 0.05 (5\%). So, the Equation (1) shows the regression model which is the initial model which estimated for this study.

$$
R=\beta 0+\beta 1 \mathrm{PE}+\beta 2 \mathrm{PI}+\beta 3 \mathrm{DA}+\beta 4 \mathrm{SW}+\beta 5 \mathrm{IT}+\beta 6 \mathrm{IC}+\varepsilon
$$

\section{where:}

$R=$ The Relevance of Financial Information;

$\beta 0=$ Intercept;

$\beta 1$ to $\beta 6=$ Coefficient of slope parameters;

$\mathrm{PE}=$ People;

$\mathrm{PI}=$ Procedures and Instructions;

$\mathrm{DA}=$ Data;

SW = Software;

IT = Information Technology Infrastructure;

IC = Internal Controls;

$\varepsilon=$ Error term.

Regression analysis performed between Accounting Information Systems (People, Procedures and Instructions, Data, Software, Information Technology Infrastructure, and Internal Controls) and relevance of financial information. The main results of the model are given in Table 9. According to this table, the coefficient of determination $R 2$ is 0.616 which means that the dimensions explain $61.6 \%$ of the relevance of financial information. The remaining $38.4 \%$ of the variation is identified by other factors not captured in this model.

The ANOVA analysis related to the regression model performed and the results given in Table 10. According to this table, F-calculated was (22.449) and the F-critical was (2.827), By comparing the values obtained in the test of this hypothesis, the calculated value is higher than the scale value. The significance value of the analysis is $(0.00<0.05)$ Therefore, the null hypothesis rejected, and the alternative hypothesis is accepted, which means that the dependent variable can explain by the independent variables at $95 \%$ confidence level.

After this examination, the detailed information about the regression analysis which includes the coefficients of independent variables, their test statistics, and the collinearity statistics are given in Table 11.

According to Table 11, three variables from independent variables namely; People, Data, and Internal Controls are significance at the 95\% confidence level. That means these variables have a significant positive impact on the relevance of financial information in Wahda Bank.

On the other hand, the other three independent variables-Software, Procedures and Instructions, and Information Technology Infrastructure are not significant and therefore have not impact on the relevance of financial information in Wahda Bank. 
Table 9. Model summary for study model.

\begin{tabular}{cccc}
\hline$R$ & R Square & Adjusted R Square & Std. Error of the Estimate \\
\hline 0.785 & 0.616 & 0.588 & 0.35056 \\
\hline
\end{tabular}

Predictors: (Constant), Internal Controls, People, Data. Dependent Variable: Relevance.

Table 10. Anova for study model.

\begin{tabular}{ccccc}
\hline Model & Sum of Squares & df & Mean Square & F \\
\hline Regression & 8.276 & 3 & 2.759 & 22.449 \\
Residual & 5.161 & 42 & 0.123 & \\
Total & 13.438 & 45 & & \\
\hline
\end{tabular}

The Relevance of Financial Information, (F Critical 3, 42, $\alpha: 0.05=2.827$ ). Predictors: (Constant), People, Data, Internal Controls.

Table 11. Coefficients for study model.

\begin{tabular}{|c|c|c|c|c|c|c|c|}
\hline \multirow{2}{*}{ Model } & \multirow{2}{*}{$\begin{array}{c}\text { Unstandardized } \\
\text { Coefficients } \\
\text { B }\end{array}$} & \multicolumn{2}{|c|}{$\begin{array}{l}\text { Standardized } \\
\text { Coefficients }\end{array}$} & \multirow[t]{2}{*}{$\mathrm{t}$} & \multirow{2}{*}{ Sig. } & \multicolumn{2}{|c|}{$\begin{array}{c}\text { Collinearity } \\
\text { Statistics }\end{array}$} \\
\hline & & Std. Error & Beta & & & Tolerance & VIF \\
\hline (Constant) & 0.418 & 0.423 & & 0.988 & 0.329 & & \\
\hline Internal Controls & 0.324 & 0.095 & 0.426 & 3.422 & 0.001 & 0.591 & 1.693 \\
\hline People & 0.248 & 0.102 & 0.266 & 2.438 & 0.019 & 0.771 & 1.297 \\
\hline Data & 0.287 & 0.142 & 0.272 & 2.028 & 0.029 & 0.510 & 1.960 \\
\hline
\end{tabular}

The assumption which must examine is multicollinearity. The Variance Inflation Factor should be lower than 10. Where, as a guideline, if VIF greater than 10 indicates a multicollinearity problem [44], where is the coefficient of determination of the model that includes all the predictors. Also, Tolerance must be higher than 0.20 . According to [45], a tolerance value lower than 0.20 suggests a multicollinearity problem.

According to Table 10, the Variance Inflation Factor (VIF) scores for all independent variables were lower than 10, and tolerance value higher than 0.20 . Therefore, this proves the absence of multicollinearity in the above model, and this satisfies the assumption of "low collinearity" [46] [47] and as a result, our model is accurate (well fitted).

Thus, the new regression Equation that represents the impact of accounting information systems on the relevance of financial information will be as shown in Equation (2).

$$
\boldsymbol{R}=0.418+0.266(\mathrm{PE})+0.272(\mathrm{DA})+0.426(\mathrm{IC})+\varepsilon
$$

Accordingly, it can argue that the main hypothesis $\mathrm{H} 1$ that assumed there is an impact of accounting information systems on the relevance of financial information was generally accepted. But when we study the sub-hypotheses, we only found hypotheses $\mathrm{H}_{1 \mathrm{a}}, \mathrm{H}_{1 \mathrm{c}}$, and $\mathrm{H}_{1 \mathrm{f}}$ are accepted. 


\section{Conclusions, Recommendations and Limitations}

From the above, the study reached several conclusions and recommendations, of which the most important are following.

\subsection{Conclusions}

What distinguishes this study is the accounting information systems divided into six elements. It is seen that there is a reliable and positive correlation between the relevance of financial information, People, Procedures and Instructions, Data, Software, Information Technology Infrastructure, and Internal Controls, based on the correlation analyses between these six elements and the element of the relevance of financial information.

Also, it is quite evident that just three elements from accounting information systems elements impact positively on the relevance of financial information namely; People, Data, and Internal Controls. Where the regression analysis of the study model shows that there a significant positive impact of these elements, on the relevance of financial information; thus, according to the regression analyses, it is evident these three elements are the critical factors in explaining the impact on the relevance of financial information in Wahda Bank. Therefore, any increase in these elements will increase the relevance of financial information, which means increasing the capability to impact the business decisions of users by assisting them to assess past, present and future events or verifying and correcting their earlier evaluations.

On the other hand, the regression analysis of study model shows that there are three independent variables Software, Procedures and Instructions, and Information Technology Infrastructure which found all of them does not impact on the relevance of financial information.

So, we can find, some of these results came compatible with the requirements of accounting information systems (AIS), through the regulations, laws, and procedures issued by the Central Bank of Libya and the Audit Bureau-Libya to apply in the Libyan accounting environment. The most important of these results:

1) The employees in Wahda bank finance department have an excellent educational qualification to perform the accounting work.

2) Accountants in Wahda bank they develop themselves to suit the requirements of the profession.

3) The attention of the bank's management with training and continuing education programs for employees in the finance department increases their level of qualification.

4) The bank's policies include specific and clear responsibilities and authorities for all employees in the finance and accounting departments.

5) The accounting information system at the bank takes into consideration various departments by provides the appropriate reports periodically to them.

6) Accounting transactions at the bank are recorded in accordance with in- 
ternational accounting standards.

7) There is at the bank a set of records and ledgers to save Data such as (Journal, General ledger and Subsidiary ledger).

8) The accounting department at the bank collections and stores data about events, resources and agents and transforms these data later into information that assists management in decision-making. Also, the bank uses efficient accounting programs and systems for processing this data.

9) The use of applications and software has contributed to managing and facilitating the work of the accounting system at the bank.

10) Dealing with the software available in the bank is easy and does not require a high degree of complexity.

11) The use of networks in the bank contributes to the exchange of data and accounting information between the parties concerned. And the bank uses advanced computers and networks systems for this purpose.

12) Internal control aims to protect the bank's assets from manipulation and misuse and to ensure the accuracy of the information contained in accounting ledgers and records. It also provides control reports on the performance of different administrative levels.

13) The information provided by the Bank's accounting information system is confidential and secure.

\subsection{Recommendations}

1) Increasing attention to training and continuing education programs for financial management personnel, especially those related to accounting information systems and international accounting standards.

2) Greater emphasis on the implementation of policies developed by the Central Bank and further defining and clarifying the responsibilities and authorities of all staff in the finance and accounting departments.

3) Increased attention to data collection that recognizes the external environment, while using effective accounting programs and systems to address this data.

4) Involving financial employees in the preparation and development of accounting information systems.

5) Work continuously on update computers, routers, networks cables, which used in a process the entering, retrieving and transferring of financial information.

\subsection{Limitations and Future Research Directions}

This study deals with the concept of accounting information systems and their impact on the relevance of financial information are within the following limits:

- Time Limits: The time limit between was 15/02/2019 and 30/05/2019 represents the temporal limit for search.

- Spatial boundaries: The spatial boundaries are in the city of Benghazi Libya 
and in Wahda bank in particular.

Therefore, the researcher suggests that future studies should be carried out using the same scale and applied to other banks or other sectors such as oil companies, and service institutions.

\section{Conflicts of Interest}

The author declares no conflicts of interest regarding the publication of this paper.

\section{References}

[1] Abdallah, A.A.J. (2014) The Impact of Using Accounting Information Systems on the Quality of Financial Statements Submitted to the Income and Sales Tax Department in Jordan. European Scientific Journal, 9, 41-48.

[2] Tsoncheva, G. (2014) Measuring and Assessing the Quality and Usefulness of Accounting Information. Journal of the University of Economics-Varna, 9, 52-64.

[3] Gaddur, R. and Ghalib, Y. (2003) A Proposal to Study the Impact of Information Technology on the Optimal Use of Resources in the Enterprise Model. Jordan Journal of Applied Sciences, 6, 178-191.

[4] Corina, M. and Nicolae, M.M. (2012) Quality of Accounting Information to Optimize the Decisional Process. Annals of Faculty of Economics, 1, 694-699.

[5] Gafarov, T. (2009) Financial Reporting Quality Control for Internal Control Implementation.

[6] Stvilia, B., Gasser, L., Twidale, M.B. and Smith, L.C. (2007) A Framework for Information Quality Assessment. Journal of the Association for Information Science and Technology, 58, 1720-1733. https://doi.org/10.1002/asi.20652

[7] Bagranoff, N.A., Simkin, M.G. and Norman, C.S. (2010) Core Concepts of Accounting Information Systems. 11th Edition, John Wiley \& Sons, Inc., Hoboken.

[8] Patel, F. (2015) Effects of Accounting Information System on Organizational Profitability. International Journal of Research and Analytical Reviews, 2, 168-174.

[9] Dandago, K.I., Rufai, A.S., et al. (2014) Information Technology and Accounting Information System in the Nigerian Banking Industry. Asian Economic and Financial Review, 4, 655-670.

[10] Saeidi, H. (2014) The Impact of Accounting Information Systems on Financial Performance-A Case Study of TCS India. Indian Journal of Fundamental and Applied Life Science, 4, 412-417.

[11] Laudon, K.C. and Laudon, J.P. (2015) Management Information Systems: Managing the Digital Firm. Prentice Hall Press, Upper Saddle River.

[12] Beach, J. (2017) What Are the Six Elements of an Information System? Techwalla Online.

[13] Fontinelle, A. (2011) Introduction to Accounting Information Systems.

[14] O’Brien, J.A. and Marakas, G.M. (2010) Management Information Systems: Managing Information Technology in the Business Enterprise. 10th Edition, McGraw Hill, New York.

[15] Aljawhar, K.A. (2011) The Relationship between the Qualitative Characteristics of Accounting Information and the Governance Rules of the Board of Directors: An Analytical Study of the Views of Accountants and Auditors. Magazine of Economic 
and Administration, 90, 103-128.

[16] Eldahrawi, K.M. and Kamel, M.S. (2000) Accounting Information Systems. New University Publishing House, Alexandria.

[17] IASB (2018) Conceptual Framework for Financial Reporting 2018.

[18] Kieso, D.E., Weygandt, J.J. and Warfield, T.D. (2016) Intermediate Accounting. 16th Edition, John Wiley \& Sons, Inc., Hoboken.

[19] Beisland, L.A. (2008) Essays on the Value Relevance of Accounting Information.

[20] Ball, R. and Brown, P. (1968) An Empirical Evaluation of Accounting Income Numbers. Journal of Accounting Research, 6, 159-178. https://doi.org/10.2307/2490232

[21] Beaver, W.H. (1968) The Information Content of Annual Earnings Announcements. Journal of Accounting Research, 6, 67-92. https://doi.org/10.2307/2490070

[22] Barth, M.E., Beaver, W.H. and Landsman, W.R. (2001) The Relevance of the Value Relevance Literature for Financial Accounting Standard Setting: Another View. Journal of Accounting and Economics, 31, 77-104. https://doi.org/10.1016/S0165-4101(01)00019-2

[23] Crockett, J. and Friend, I. (1966) Some Estimates of the Cost of Capital to the Electric Utility Industry, 1954-57. American Economic Review, 56, 333-391.

[24] Amir, E., Harris, T.S. and Venuti, E.K. (1993) A Comparison of the Value-Relevance of US versus Non-US GAAP Accounting Measures Using form 20-F Reconciliations. Journal of Accounting Research, 31, 230-264. https://doi.org/10.2307/2491172

[25] Beaver, W.H. (2002) Perspectives on Recent Capital Market Research. The Accounting Review, 77, 453-474. https://doi.org/10.2308/accr.2002.77.2.453

[26] Francis, J. and Schipper, K. (1999) Have Financial Statements Lost Their Relevance? Journal of Accounting Research, 37, 319-352. https://doi.org/10.2307/2491412

[27] Ohlson, J.A. (1995) Earnings, Book Values, and Dividends in Equity Valuation. Contemporary Accounting Research, 11, 661-687. https://doi.org/10.1111/j.1911-3846.1995.tb00461.x

[28] Ball, R. (2006) International Financial Reporting Standards (IFRS): Pros and Cons for Investors. Accounting and Business Research, 36, 5-27. https://doi.org/10.1080/00014788.2006.9730040

[29] Harris, M.S. and Muller, K.A. (1999) The Market Valuation of IAS versus US-GAAP Accounting Measures Using Form 20-F Reconciliations. Journal of Accounting and Economics, 26, 285-312. https://doi.org/10.1016/S0165-4101(99)00003-8

[30] Niskanen, J., Kinnunen, J. and Kasanen, E. (2000) The Value Relevance of IAS Reconciliation Components: Empirical Evidence from Finland. Journal of Accounting and Public Policy, 19, 119-137. https://doi.org/10.1016/S0278-4254(00)00002-8

[31] Bartov, E., Goldberg, S.R. and Kim, M. (2005) Comparative Value Relevance among German, U.S. and International Accounting Standards: A German Stock Market Perspective. Journal of Accounting, Auditing \& Finance, 20, 95-119. https://doi.org/10.1177/0148558X0502000201

[32] Lin, Z.J. and Chen, F. (2005) Value Relevance of International Accounting Standards Harmonization: Evidence from A- and B-Share Markets in China. Journal of International Accounting, Auditing and Taxation, 14, 79-103. https://doi.org/10.1016/j.intaccaudtax.2005.08.001

[33] Callao, S., Jarne, J.I. and Laínez, J.A. (2007) Adoption of IFRS in Spain: Effect on the 
Comparability and Relevance of Financial Reporting. Journal of International Accounting, Auditing and Taxation, 16, 148-178.

https://doi.org/10.1016/j.intaccaudtax.2007.06.002

[34] Paglietti, P. (2010) Earnings Management, Timely Loss Recognition and Value Relevance in Europe Following the IFRS Mandatory Adoption: Evidence from Italian Listed Companies. Economia Aziendale Online, 1, 97-117.

[35] Alzoabaie, Z.A. (2001) Accounting Information Systems and Their Impact on the Relevance and Reliability of Accounting Information-A Field Study on Industrial Companies in Jordan.

[36] Aldaya, M.Y. (2009) The Impact of Using Accounting Information Systems on the Quality of Financial Data in the Services Sector in the Gaza Strip (Field Study). The Islamic University, Gaza?"

[37] Alshami, A.Y. (2009) The Effect of the Qualitative Characteristics of Accounting Information on the Quality of Financial Reports of Commercial Banks Working in Republic of Yemen.

[38] Van Beest, F., Braam, G. and Boelens, S. (2009) Quality of Financial Reporting: Measuring Qualitative Characteristics. Nijmegen Cent. Econ. (NiCE), Work. Pap. 9-108.

[39] Abuharb, M.Y. (2009) The Extent of Relevance and Reliability of the Output of Accounting Information Systems, in View of Applying Fair Value by Commercial Banks in Jordan. The Arab Academy for Banking and Financial Sciences, Cairo.

[40] Nunnally, J. and Bernstein, I. (1994) Psychometric Theory. 3rd Edition, McGraw-Hill, New York

[41] Uma Sekaran, R.B. (2016) Research Methods for Business: A Skill Building Approach. 7th Edition, Wiley, Hoboken.

[42] Carmines, E.G. and Zeller, R.A. (1979) Reliability and Validity Assessment. Sage Publications, Thousand Oaks, 17. https://doi.org/10.4135/9781412985642

[43] Hair, J.F., Black, W.C., Babin, B.J. and Anderson, R.E. (2010) Multivariate Data Analysis : A Global Perspective. 4th Edition, Pearson Education Limited, London.

[44] Myers, R.H. and Myers, R.H. (1990) Classical and Modern Regression with Applications. Duxbury Press, Belmont, 2.

[45] Menard, S. (2001) Applied Logistic Regression Analysis. 2nd Edition, Sage Publications, Inc., Thousand Oaks. https://doi.org/10.4135/9781412983433

[46] Darlington, R.B. (1968) Multiple Regression in Psychological Research and Practice. Psychological Bulletin, 69, 161-182. https://doi.org/10.1037/h0025471

[47] Keith, T.Z. (2019) Multiple Regression and Beyond: An Introduction to Multiple Regression and Structural Equation Modeling. 3rd Edition, Routledge, Abingdon-on-Thames. https://doi.org/10.4324/9781315162348-1 